\title{
SMALL INVESTORS: CHALLENGES AND BENEFITS OF IPO - A CASE STUDY IN A SMALL BUSINESS IN THE REGION OF THE CAPÃO REDONDO - SP
}

\author{
Loide Priscila Cacheche \\ Universidade Adventista de São Paulo, Brazil \\ E-mail: eduardo-biagi@hotmail.com \\ João Almeida Santos \\ Universidade Adventista de São Paulo, Brazil \\ E-mail: professoralmeida@ig.com.br \\ Eduardo Biagi Almeida Santos \\ Universidade Nove de Julho, UNINOVE, Brazil \\ E-mail: eduardo-biagi@hotmail.com \\ Getulio Akabane \\ Universidade Anhanguera, Brazil \\ E-mail: getulio@akabane.adm.br \\ Submission: 28/07/2014 \\ Revision: 03/09/2014 \\ Accept: 02/10/2014
}

\section{ABSTRACT}

The purpose of this paper is to analyze the importance of knowledge of managers about market capitals (in terms of benefits and challenges) and the relevance of the inclusion of small business context in this market. A case study was conducted by open questions interview with a CEO of a small business in Sao Paulo. Results showed that despite the CEO has knowledge about the capital market; the company was not structurally prepared to accept the challenges of capital markets.

Keywords: Market capitals, Case Study, Small business 


\section{INTRODUCTION}

Brazil has been through a lot of transformations in the economic environment in the last decade. One of these transformations occurs by the growth of SMEs (Small and Medium Enterprises) companies that each day has been increasing significantly in the Brazilian economy.

SMEs have helped in strongest way the Brazilian economy. SMEs operates through a various sectors, such as trade, industry, services, and online. These companies are important for the local economy (i.e. creating jobs to local population). It is remarkable that these companies also help in the evolution of large business, making incomes that they don't produce.

However, many times SMEs cannot prosper for long in the local market, they eventually stop to operate in a short period. This occurs by the lack of credit, absence of technical support, deficiency of adequate management and also the deficiency of qualified personnel (NAJBERG; PUGA; OLIVEIRA, 2000).

Several companies have solved their financial problems through bank loans, which in fact led to its increasing debt default rate. Bank loans can bring an immediate solution, but in long term can cause a lot of problems for managers. Debts are difficult to be resolved, also affecting the working capital of the company. To solve these financial problems, many companies have sought a solution through IPO. Given the difficulties that the SMEs seek strength in the financial sector to get credit to consolidate their companies in the market. A new strategy emerges, the IPO

The IPO has benefits and challenges for a company to go public for the stock market. But this strategy may be favorable since the company knows the right moment to perform this action with a well-defined corporate structure and that if it fits according to the rules of the CVM (Comissão de Valores Mobiliários correspondent to Securities and Exchange Commission) following all the procedures that must be performed. The objective of this research is to show advantages and challenges of IPO by the methodology of case study with a small enterprise. 
DOI: 10.14807/ijmp.v6i1.255

\section{STRUCTURE OF CAPITAL MARKET AND ITS IMPORTANCE}

Even before talk about the importance of the capital market is important to know its definition. According to Pinheiro (2012) Capital markets can be defined as a set of institutions and instruments relating to title and securities, in order to direct resources to selling agents. This statement shows the financial market dynamics in the sale and purchase of shares on the Stock Exchange which reinforces their resources for the organization to achieve mobility and liquidity of their securities with institutions and instruments for trading.

The capital market has emerged in Brazil at 1964 when the government decided to revamp the financial system thereby creating laws to better structure to the Stock Exchange and authorized financial institutions

This was a mark for the Brazilian economy, because from that moment the capital market has more coordination and transparency to the shareholders who invested in shares. This development was taking place so that the capital market to stay well organized allowed investors to have more certainty and confidence to invest their capital by the creation of Law No. 4.728/65 - Law of Financial and Capital Market that actually are disciplined by the Conselho Monetário Nacional brasileiro and supervised by the Banco Central brasileiro (BRANCO, 1965). This law backs up and protects the investor from possible irregularities and fraud within companies where they held their investments.

The creation of the stock market was based on the following principles (PINHEIRO 2012, p 174.): Contribute to economic development, acting as a driver of capital for investment, encouraging the formation of private savings; Allow and guide the structuring a society based on a market economy, allowing the collective participation broadly in wealth and economic results.

The principles that guide the creation of capital markets foster and encourage economic growth in the country, providing an opportunity for investors to participate in the development of it through negotiations on the stock exchange, and these principles also stimulate a form of security and financial health for an organization which has private savings. The capital market consists of two parts, Primary and Secondary Market. Figure 1 shows this structure: 
DOI: 10.14807/ijmp.v6i1.255

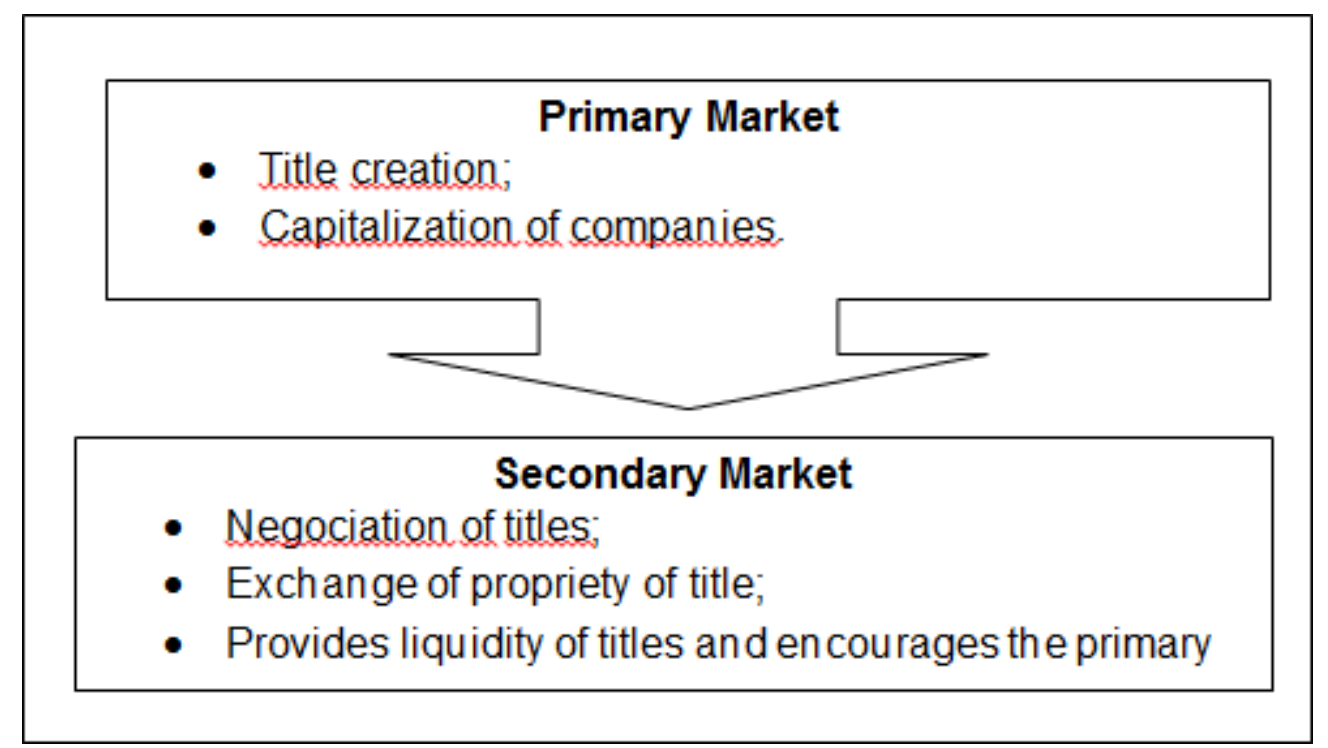

Figure 1 - Structure of capital market.

Source: Pinheiro (2012, p. 174)

In the primary stock market, shares are traded by way of subscription, where organizations finance their projects. The secondary stock market aims to provide liquidity to investors, allowing a buyer and a seller to invigorate the primary market. And it is noteworthy that the secondary market should have the following attributes: Transparency, Liquidity and Efficiency (PINHEIRO, 2012).

Knowing the structure and importance of the capital market is important for everyone, especially for investors who are interested to enter in the stock market and seek more knowledge about the functioning of the Brazilian economy. It is worth emphasizing that the capital market has very important role in the economic development of the country.

Importantly this research with investments in the stock market the organization seeks growth and sustainability in the local market, which in turn will create more income generation for the population through employment.

The entry of an organization in the stock market brings financial results for the shareholders, be they positive or not. In the aspect of the damage of organizations, many of them sighted many difficulties and barriers to their inclusion in the stock market, but this strategy can be very profitable for organizations with structure prepared for this new challenge (MODIGLIANI; MILLER, 1958).

Therefore the search for knowledge is essential for the new investor who longs to enter this market, knowing the structure, the benefits it brings to society and the 
DOI: 10.14807/ijmp.v6i1.255

economy and do an analysis of how it acts directly on the lives of individuals and companies are required important for any investor to enter the stock market.

\section{BENEFITS AND CHALLENGES OF IPO}

This section will address some of the reasons that organizations decide to open its capital to the securities market and also will analyze the disadvantages of having shares on the Stock Exchange. Most organizations already passed or will pass a financial crisis, as there are many factors such as acquisition of machinery, investment in new projects, accumulation of losses and other reasons that has large debts or expenses on tax charges that imposed by government, which cannot fail with the operation and legality (HUBBARD, 1997).

For these and other reasons managers seeking strategies to reverse this situation and make the most profitable and established company in the market, thus reducing the possibility of their mortality. And a strategy that has been adhered to by many companies today is the opening of their capital in the stock market.

This idea is well placed as follows by Pinheiro: organizations must aim to make financing of its investment or even restructuring of its liabilities have the alternative of raising funds by securities also helped us with financing banks. (PINHEIRO, 2012). The following Figure 2 shows some benefits and challenges of opening the capital of a company.

By observing this comparison chart you can see that there is a significant number of disadvantages to going public, so the inclusion of organizations in the stock market should not only be motivated to obtain funding, this action is very costly and bureaucratic to companies. For it is evident that analyze along with the benefits come responsibilities and obligations to be fulfilled. However despite many obligations and a high cost to keep the organization in the stock market is important to remember the advantages that the IPO may allow an organization. With this action she has more opportunities to compete with the competition making this opening a strategy which if managed effectively can bring positive results for organizations (HARRISON, J., M.; KREPS, 1978). 
DOI: 10.14807/ijmp.v6i1.255

\begin{tabular}{|c|c|}
\hline Benefits & Challanges \\
\hline $\begin{array}{l}\text { - Increase cash for the company and / } \\
\text { or liquidity for shareholders in a } \\
\text { secondary placement issue. } \\
\text { - Creation of a currency exchange in } \\
\text { the acquisition or incorporation with } \\
\text { another company. } \\
\text { - Increased visibility, allowing for } \\
\text { possible fusions, acquisitions or } \\
\text { mergers. } \\
\text { - Diversification of funding sources } \\
\text { (including optimizing the profile of } \\
\text { debt / equity) enabling effect growth } \\
\text { strategies. } \\
\text { - Possibility of differentiated } \\
\text { remuneration of staff through the } \\
\text { purchase of company stock options. }\end{array}$ & $\begin{array}{l}\text { - Relevant costs related to the IPO and } \\
\text { maintenance of Listed Company. } \\
\text { - Increase in recurring costs and } \\
\text { compliance costs. } \\
\text { - Need to establish a structure Investor } \\
\text { Relations. } \\
\text { - Need for meeting specific standards } \\
\text { regarding disclosure of information, } \\
\text { including material facts that may } \\
\text { affect the pricing of the action. } \\
\text { - Path of no return: close the capital of } \\
\text { a public company is difficult and very } \\
\text { costly. } \\
\text { - Less flexibility in decision making and } \\
\text { performance pressure. } \\
\text { - Restrictions of negotiation with } \\
\text { shareholders with privilege } \\
\text { information. } \\
\text { Vulnerability to hostile takeover } \\
\text { attempts. }\end{array}$ \\
\hline
\end{tabular}

Figure 2 - Benefits and challenges of IPO

Source: Alves e Clark (2011).

Moreover, with the IPO organizations start to incorporate corporate governance, which is defined as "the system by which organizations are directed, monitored and encouraged, by relationships between owners, board of directors, management and control bodies " (Instituto Brasileiro de Governança Corporativa, IBGC, 2009).

The Corporate Governance allows for clarity and for monitoring its members leaving them abreast of what happens in the organization, thus the decisions taken by the managers should be based on compliance with good corporate governance practices, thereby avoiding financial scandals involving them, with these practices put into action there is an incentive for the organization to work with more professionalism through a transparent and ethical work (GABAIX, 2005).

Corporate governance has principles that guide them, they are: Transparency, which may help promote feelings of confidence both internally and with third parties. Concerns information to guide management actions and collaborate to create value; Equity, to treat fairly all partners and stakeholders; Accountability, provided by agents of governance, which assume all the 
consequences that their actions may have; Corporate responsibility, sustainability of the organization must be preserved by the agents of governance, aiming his longevity in the business definition incorporates considerations of social and environmental issues (IBGC, 2009).

These principles were suggested by IBGC for a more effective and transparent within organizations that open their capital management, thus enabling an alignment of interests making the same manager to make decisions favorable for shareholders and not their own interests. If indeed these principles are put into practice the organization may have more longevity in the market becoming more sustainable and consolidated. The challenges to go public in the stock market are different even for large companies, but small investors should start thinking strategically forward thinking, innovation and sustainability analyzing the potential and possibilities of opening their resources for shareholders an interest in their respective companies (JEGADEESH, N.; TITMAN, 1993).

\section{THE IMPORTANCE OF SMES IN BRAZILIAN ECONOMY}

As already stated in the introduction of this paper, SMEs have a relevant role in our society, because they have grown quite significantly help in the economic growth of the country, so it's important to know as it has been this development. Recognizing that these companies leverage the development of the economy is important that they are consolidated in the market and it is necessary to adopt strategies. And to emphasize the importance of SMEs in the Brazilian economy SEBRAE highlights via IBGE (Brazilian Institute of Geography and Statistics) surveys the significant number of small and midsize businesses.

Table 1 shows the size, the branch of activity and quantity that there are legal firms in Brazil comparing the years 1996 to the latest survey published in 2002.

Table 1 clearly shows the development of small enterprises in Brazil from 1996 until 2002, primarily micro businesses, the numbers show that these companies have much growth potential thereby helping the country's economic development and providing opportunities not only for investors and shareholders, but also for people generate income through their work. This growth comes to reflect the economic reality presently lived in Brazil. It is a developing country with people who want and need to achieve financial independence, thus associating with a partner or even a 
INDEPENDENT JOURNAL OF MANAGEMENT \& PRODUCTION (IJM\&P)

http://www.ijmp.jor.br

v. 6, n. 1, January - March 2015

ISSN: 2236-269X

DOI: 10.14807/ijmp.v6i1.255

family company and consolidating new business ventures as a strategy formulation and also reaching personal goals and accomplishments.

Table 1: Brazil - Number of formal enterprises by size and sector: 1996 - 2002

\begin{tabular}{|l|c|c|c|c|r|r|r|r|r|c|}
\hline \multirow{2}{*}{} & \multicolumn{2}{|c|}{ Micro } & \multicolumn{2}{c|}{ Small } & \multicolumn{2}{c|}{ Medium } & \multicolumn{2}{c|}{ Large } & \multicolumn{2}{c|}{ Total } \\
\cline { 2 - 10 } & 1996 & 2002 & 1996 & 2002 & 1996 & 2002 & 1996 & 2002 & 1996 & 2002 \\
\hline Industry & 332.049 & 439.013 & 27.011 & 37.227 & 6.375 & 6.548 & 1.521 & 1.430 & 366.956 & 484.218 \\
\hline Construction & 81.923 & 116.287 & 7.177 & 8.282 & 1.473 & 1.694 & 205 & 221 & 90.778 & 126.484 \\
\hline Commerce & 1.608 .521 & 2.337 .889 & 68.411 & 105.891 & 4.376 & 4.862 & 2.896 & 2.846 & 1.684 .204 & 2.451 .488 \\
\hline Service & 934.256 & 1.712 .418 & 78.516 & 122.609 & 8.303 & 10.548 & 8.850 & 10.605 & 1.029 .925 & 1.856 .180 \\
\hline Total & 2.956 .749 & 4.605 .607 & 181.115 & 274.009 & 20.527 & 23.652 & 13.472 & 15.102 & 3.171 .863 & 4.918 .370 \\
\hline
\end{tabular}

Source: IBGE, Diretoria de Pesquisas, Coordenação de Serviços e Comércio, Pesquisa Anual de Serviços (2004).

\section{METHODOLOGY}

The present study used an approach of investigation that is constituted as a case study. This approach was well established by Yin says that in his writings the same as a method of empirical research that investigates a phenomenon, usually within a real contemporary context, when the boundaries between phenomenon and context are not clearly defined (YIN, 2001).

The source used for the basis of this paper was the literature review which in turn is developed based on literature, consisting mainly of books and scientific papers (GIL, 2002, p 44). Beyond this material were also used institutional sites that helped with the research with updated information about the studied subject.

This method allows the researcher to make an analysis of a real situation with a certain phenomenon, allowing him to clarify the distance between the phenomenon and context. Case study was conducted through open questions interview with CEO of a small company of trading business in the region Capão Redondo in São Paulo was performed to assess knowledge of the topic proposed in this study. The company was chosen by convenience of the authors. The company fit in small business and its interest to IPO. This organization operates for 40 years in Capão Redondo / SP region, offering their products to local customers.

This research has a qualitative approach, which in turn, makes use of description, understanding and interpretation of facts and analyzed deeply and 
DOI: 10.14807/ijmp.v6i1.255

intensely the phenomenon (MARTINS; THEÓPHILO, 2007). Through this analysis it is possible to know more about the reality of the company researched.

\section{ANALYSIS AND INTERPRETATION OF DATA}

The authors conducted an interview with the CEO of a company from the commercial sector in the region Capão Redondo in São Paulo. To achieve the proposed objective of this study, a questionnaire containing nine open questions was used to assess the knowledge and perception of the interviewee about market capital.

\subsection{Have you ever heard about capital market?}

The respondent showed his knowledge about capital market stating that know capital market and the stock exchange.

Through this response can be noted that the CEO have knowledge of the stock market and demonstrate always seek knowledge by newspapers and specialized courses which aims to inform entrepreneurs about economics, politics and other issues.

As shown in this research, it is extremely important that investors and managers of organizations to seek information about the economy and also knowledge about the stock market, to have a good foundation when deciding to enter this market.

\subsection{What kind of benefits do you think the capital market can bring to the economy?}

In the opinion of the interviewee invest in the stock market can be a risk. But managers can be successful if makes a constant monitoring of its investments, a necessary control because of the market fluctuations.

The stock market can bring risks to the investor, but its positively oriented to society, because as mentioned in this study, through investments of companies there is a greater propensity for economic development, Pinheiro (2012) confirms this idea in his work. 
DOI: 10.14807/ijmp.v6i1.255

\subsection{Do you think it interesting that small investors have a savings or some sort of investment banking with Certificate of Deposit?}

The respondent stated that it is important that the company has a reserve for emergencies, and that this reservation is not necessary an investment. He also knows the $C D$, but not found very advantageous to your business.

It is true that having a financial reserve for possible emergencies is a form of prevention in times of financial distress of a company. Pinheiro (2012, p. 74) states that the capital market has also the function of stimulating the formation of private savings.

\subsection{Have you heard of IPO? If you could do an IPO do you believe it would be interesting for your business?}

The CEO of the company showed to have knowledge about IPO and said it would not be interesting for your company because it does not have enough structure to emerge in this strategy.

The insight in this response make it clear that some small investors still fear to invest in the stock market, even by structural problems facing by the company, and the fact that this strategy has risks, but he agrees that the best companies structured as medium and large ones may think about the possibility of opening its capital to improve your business.

This thought of the interviewed can be based on the obligations to be fulfilled by CVM (Comissão de Valores Mobiliários correspondent to Securities and Exchange Commission) regulations.

\subsection{What opportunities and difficulties do you think can happen when a company goes public on the stock exchange?}

The interviewee has mentioned the answer of question 2, showing that investing in stocks can be a risk, where the company or investor can make profit or not. There are many challenges, as showed in figure 2, is evident that the disincentives for the IPO are higher, but if the control actions are managed efficiently this strategy can bring results favorable for organizations. 
DOI: 10.14807/ijmp.v6i1.255

\subsection{Have you already received guidance of SEBRAE (Serviço Brasileiro de Apoio as micro e pequenas Empresas - Brazilian Support Service for Micro and Small Enterprises) about IPO?}

The interviewee responded positively, saying he received guidance SEBRAE about capital market and other issues. But he was not interested, because in his view SEBRAE provides guidance only for the professionalization of the employees and for the company itself.

SEBRAE existed since 1972 and aims to give support to Micro and Small Enterprises and intended to promote competitiveness and sustainable development of small and micro enterprises.

\subsection{In the economic context in which we live, how do you see the importance of small and medium enterprises to the country's economy?}

According to the respondent SMEs give much profit to the government through the taxes they impose, he emphasized that the government should implement a single tax rate to encourage the longevity of companies. The interviewee's answer clearly that SMEs move large part of the economy.

The opinion of the manager on a single rate may be feasible in the sense that the result of this action is that these companies become more sustainable in the market and lower your mortality rate by several factors.

\subsection{Have you ever heard about Corporate Governance? How these practices could help the management of your company?}

The interviewee reported that does not know this term, but know this management structure. But he does not believe that this administration would be interesting for your company. As mentioned in previous issues the manager does not find interesting IPO.

Corporate governance is present in the management of the companies, because this practice makes all the investments and strategies clear for investors. 
DOI: 10.14807/ijmp.v6i1.255

\subsection{With the economic difficulties experienced by the country, do you believe that small and medium-sized businesses may find the stock market a possible solution to their mortality and financial problems?}

According to respondent, the IPO is not a good idea for sustainability of a small or medium business. To him one of the strategies that can be taken is to make a provision of that will be spent by the company through planning, and also a government plan to reduce taxes thus creating a single-rate form of taxation.

For the analysis of this interview and the basis of our study it can be seen that there is a barrier at the opening of capital, mainly because of the risks. The investor said during the interview that small businesses do not have to open its capital structure; this is possibly the reason why he believes the IPO does not solve the financial difficulties.

\section{FINAL CONSIDERATIONS}

The current economic environment has been changing every day, where only survive organizations that adapt to the economic reality, so it is essential that organizations seek consistent and innovative strategies to stabilize and consolidate in the environment making it sustainable preserving their longevity.

There are many factors that lead the organization to leave the market; however, there is a crucial factor for many of them, which is the financial issue.

With this organizations started to formulate strategies intended to expand their business. One strategy adhered by large companies is the IPO, but currently this strategy is not only large companies, some SMEs have adhered to this strategy, which if managed effectively can bring good results for the organization.

The IPO is costly and bureaucratic; this fact was evidenced by the interview of the CEO. The main difficulty faced by the company was the risk, although the theory shows the positive points of this strategy, we note that in practice the negative points are very relevant.

Knowledge and innovation should be a form of survival for companies wishing to consolidate in the market. And the manager who has no motivation for these two items may lag in this increasingly competitive market. Currently there are several strategies for companies to be consolidated and one that can be viable is IPO. To 
INDEPENDENT JOURNAL OF MANAGEMENT \& PRODUCTION (IJM\&P)

http://www.ijmp.jor.br

v. 6, n. 1, January - March 2015

ISSN: 2236-269X

DOI: 10.14807/ijmp.v6i1.255

develop this action, managers has to study and a mind focused on innovation, because they have to make the process as much clear and advantageous they can.

\section{REFERENCES}

ALVES, F.; CLARK, I. (2011) Como abrir o capital da sua empresa no Brasil (IPO): Início de uma nova década de crescimento. Manual BM\&F Bovespa e PWC.

GIL, A. O. (2002) Como Elaborar Projetos de Pesquisa. Atlas, 4 ed, São Paulo.

INSTITUTO BRASILEIRO DE GOVERNANÇA CORPORATIVA, IBGC. (2009)

Relatório anual. 2009. Available at: http://www.ibgc.org.br ${ }_{2}$ accessed date july, 09, 2013.

MARTINS, G. A.; THEÓPHILO, C. R. (2007) Metodologia da Investigação Científica para Ciências Sociais Aplicadas. Atlas, São Paulo.

NAJBERG, S.; PUGA, F. P.; OLIVEIRA, P. A. S. (2000) Sobrevivência das firmas no Brasil: dez. 1995/dez. 1997. Revista do BNDES, Rio de Janeiro, v. 7, n. 13, p. 3348, jun.

BRANCO, H., C. (1965) LEI No 4.728, DE 14 DE JULHO DE 1965. Available at: http://www.planalto.gov.br/ccivil_03/leis/14728.htm._Accessed date september, 10, 2013

GABAIX, X.; GOPIKRISHNAN, P., PLEROU, V.; STANLEY, H., E. (2005) Institutional investors and stock market volatility. National Bureau of Economic Research. 2005.

HARRISON, J., M.; KREPS, D., M. (1978) Speculative investor behavior in a stock market with heterogeneous expectations. Quarterly Journal of Economics.

HUBBARD, R., G. (1997) Capital-Market imperfections and investment. National Bureau of economic research.

IBGE (2004) Diretoria de Pesquisas, Coordenação de Serviços e Comércio, Pesquisa Anual de Serviços, Número de empresas por segmento. Manual de demografia das empresas.

JEGADEESH, N.; TITMAN, S. (1993) Returns to buying winners and selling losers: implications for stock market efficiency. The Journal of finance.

MODIGLIANI, F.; MILLER, M., H. (1958) The cost of capital, corporation finance and the theory of investment. The American Economic Review.

PINHEIRO, J. L. (2012). Mercado de capitais: fundamentos e técnicas. Atlas, 6 ed, São Paulo.

PORTAL DO INVESTIDOR. Entendendo o Mercado de valores. Available at: http://www.portaldoinvestidor.gov.br/menu/primeiros_passos/Entendendo_mercado_ valores.html ${ }_{2}$ accessed date june 11, 2013.

SEBRAE. Quem são os pequenos negócios? Available at:

http://www.sebrae.com.br/sites/PortalSebrae/estudos_pesquisas/Quem-s\%C3\%A3oos-pequenos-neg\%C3\%B3cios\%3F,destaque,5, accessed date july 09, 2013. 
INDEPENDENT JOURNAL OF MANAGEMENT \& PRODUCTION (IJM\&P)

http://www.ijmp.jor.br

V. 6, n. 1, January - March 2015

ISSN: 2236-269X

DOI: 10.14807/ijmp.v6i1.255

YIN, R. K. (2001). Estudo de Caso: planejamento e métodos. Bookman, 4 ed, São Paulo. 